IJLRES - International Journal on Language, Research and Education Studies ISSN: 2580-6777 (p); 2580-6785 (e)

Vol. 1, No. 2, 2017

Page: $312-321$

\title{
COMMUNICATIONS IN THE ORGANIZATIONAL DECISION MAKING TO OVERCOME THE CONFLICT
}

\author{
Fifi Hasmawati \\ Lecturer of School of Post Graduate \\ State Islamic University of North Sumatra, Indonesia \\ fifihasnawati@uinsu.ac.id
}

\begin{abstract}
This study aims to explore the extent to which communication can resolve conflicts within the organization. Conflict within the organization can occur at any time, either in the form of conflict between individuals as members of the organization, as well as conflicts between members and organizations. Conflict is certainly very unfavorable for leadership because it will cause difficulties in moving members to work together, in an effort to achieve common goals. In this condition the participation of members not only decreases, but also eludes and challenges as a sign of less or ineffective leadership. Conflict encourages individuals to seek friends to show their self-solidarity and problems, resulting in grouping of members opposed to others, either explicitly or clandestinely.
\end{abstract}

Key Words; Communication, Organizational decision making, Conflict

\section{INTRODUCTION}

In facing conflict, the leader must always try not to participate into the elements that inflame and menguncing conflict that occurred. Leaders should avoid attitudes and behavior of favoritism and favoritism that is detrimental to the organization. Likewise, leaders should not allow the conflict to continue so that organizational goals are difficult to achieve. Effective leaders must be able to resolve ongoing conflicts with attitudes and behaviors to assist each member, without creating the impression of favor to benefit / harm one party, to realize the interests of the organization or common interests. The leader of the organization in dealing with the conflict must demonstrate attitudes and behaviors aimed at saving the organization, which if possible avoid the adverse effects of members of the organization.

An important aspect of organizational life that concerns relationships among groups within organizations is that the symptoms of bad relationships are easily recognizable. A congestion in the workflow or lack of coordination among groups is 
usually easy to observe. ${ }^{1}$ Poor communication or failure to exchange information adequately may be a symptom accompanying a lack of coordination. Delays and errors often cause tension and negative feelings. If the group has to depend on each other to finish the job, the symptoms are more dramatic. The conflicts of groups are expressed in the same way as interpersonal contradictions. Criticism, strife, selfconsciousness and intentional neglect of others are clear indicators of difficult relationships, as opposed to showing a satisfactory relationship.

\section{LITERATURE REVIEW}

Conflict can be interpreted by differences, disagreements and disputes. ${ }^{2}$ In addition, the conflict is also said to be a process that when one party feels that the other has negatively influenced or will immediately affect negatively, something that the first party noticed. According to Prof.Veithzal, this understanding covers a broad range of conflicts experienced by people in organizations, objectivity mismatches, differences in interpretation of facts, disagreements based on expectations of interpretation of facts, disagreements based on expectations of behavior, and the like. Conflicts can be seen from several angles of view, they are:

\section{Traditional Views}

This view assumes that all conflicts are bad and negative, synonymous with harmful terms of violence, but must be avoided and overcome. According to this view, conflict is a thing to be avoided, there are some things that form the basis of this view:

1. Conflict is basically not good, does not need to happen and must be solved

2. Conflicts arise from non-lyrical communication, lack of trust, and the absence of openness from the interconnected parties].

3. The environment has a great role to play against the possibility of conflict

4. Humans are essentially creatures that have positive attributes, cooperate, and can be trusted.

\section{Human Interaction Views}

This view holds that conflict is a natural and inevitable result in every group

\footnotetext{
${ }^{1}$ Pace,R. Wayne \& Faules, Don.F “ Komunikasi Organisasi, Strategi Meningkatkan Kinerja Perusahaan”, PT R,emaja Rosdakarya, Bandung, 2005, p. 21

2 Pace, R Wayne (1983). Organization communication, Faondation for Human Resource Development. New Jersey: Prentice Hall, Inc, p. 76
} 


\section{Interactional Views}

This view holds that conflicts are not only a positive force within a group, but also absolutely necessary for a group to perform effectively, since this view is often referred to as a modern outlook.

Conflict usually has both positive and negative connotations, depending on how to view the nature of the conflict and its effect on the effectiveness of the achievement of organizational goals. As a result of these two different ways of viewing, a view of conflict arises, that is, traditional or old-fashioned opinions and modern income. This second view argument has the following self-contained characteristics of the conflict:

1. Conflict is good and necessary so that conflict is an avoidable fact

2. Conflicts arise due to various activities such as efforts to gain respect, fulfillment of various needs, status, responsibilities, even also to gain power.

3. There are several factors in the self that cause conflict such as heredity and other psychological aspects

4. Recognize that humans are basically not bad. But man himself will be driven by various symptoms, aggressive, self-seeking and competing niches.

There are a number of issues that conflict parties may be concerned about:

1. Facts, situations or problems that exist at the time

2. Methods, the best way to achieve goals

3. Purpose, what should be achieved and

4. Value, support both quality and long-term goals

Thus a conflict occurs, if reality shows the onset of symptoms as follows:

1. The existence of two or more parties individually or in groups involved in an opposite interaction

2. There are contradictory in achieving the objectives and or the existence of an opposing norm or value.

3. The existence of interactions marked by the planned behavior to mutually eliminate, reduce, and suppress against other parties to obtain victory such as, status, responsibility, needs and so forth.

4. The existence of actions that face each other due to conflict 
5. The existence of imbalance due to the efforts of each party related to

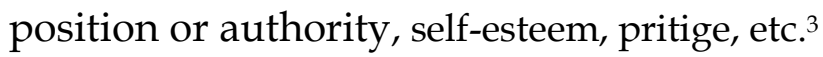

Although conflicts are often perceived as negative, research results show that certain conflicts are good for an organization and that it can improve organizational effectiveness, but after a certain point the conflict becomes extreme can undermine the work performance of the organization.

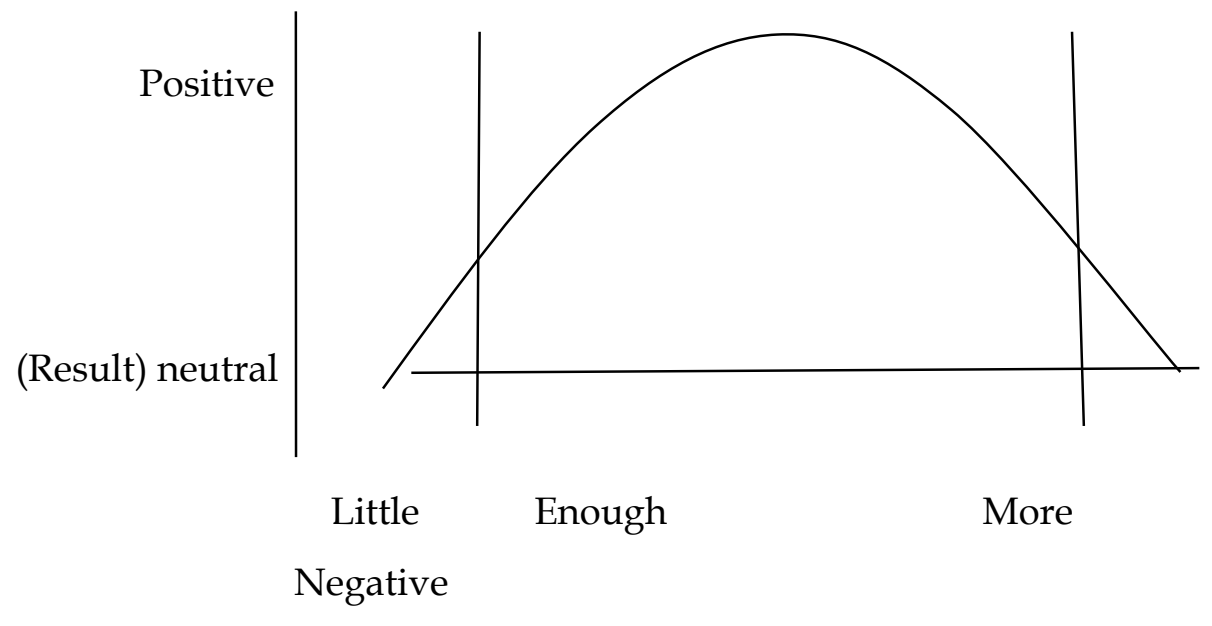

Moderate High
(Intensity)

Picture: The relationship between conflict intensity and accomplished outcomes

(Brown, 1966: 8)

In the chart above the working group, department or organization experiencing too few conflicts, tend to experience situations, apathy, lack of creativity, doubts to make decisions, and times to accomplish tasks exceeded. But on the other hand the excessive conflict, and meyebaabkan shrinking performance of organizational work, because there will be symptoms, political battles, dissatisfaction, lack of teamwork, and the number of employees who go out into the relevant organiasai. The appropriate types and levels of conflict, energize the people within the organization concerned towards a conducive environment.

3 Pondy, LR, (1976). Organization Conflik Management, in MD Dunnette (ed)", handbook of Industrial and Organization Psychology, Chicago: Rand McNally, p. 165 


\section{METHODOLOGY}

This is literature study with approach of exploring various sources of organization theory related to problem solving. the researcher conducted in-depth literature review in an attempt to find a suitable model in theory which can then be applied by the organization to solve the problems that occur both internally and externally.

\section{FINDINGS AND DISCUSSION}

There are five forms of personal conflict, they are;

1. Competitors or persistent warriors. People who have this style pursue their own interests rather unjustly and generally at the expense of members of the laon in groups. Fervent warriors see defeat as a sign of weakness, declining status and a collapsed self-image. Victory is the only worthy goal, which is accomplishment and happiness

2. Collaborators or troubleshooters. People who use this style try to create situations that allow the goals of all groups to be achieved. The troubleshooter is trying to find a solution that everyone can accept. Victory or defeat is not a way of looking at a conflict.

3. Compromiser or pedamai penyiasat. The person using this style assumes that everyone who is involved in a conflict is capable of accepting defeat, and he seeks to find a position that can be executed. A pattern of "succumbing" often develops.

4. Accommodator or friendly helper. People who use this style are less assertive and cooperative enough, ignoring their own interests for the sake of others. A friendly helper feels that alignment should be upheld and that anger and confrontation are bad. When a decision is reached, the accomodator may support the decision and hope that someday, he has stated several objections.

5. Impersonal avoidance or conformity. People who use this style tend to view conflict as unproductive and a little punitive. So avoidance away from an uncomfortable situation by refusing to get involved. The result is usually an impersonal reaction to a decision and a little commitment to future action.

Sometimes, when conflicts occur, we tend to do and say things that perpetuate conflicts rather than reducing or eliminating them. Although it is often difficult to do, 
there are usually several actions that can be taken to start conflict reduction. The opposition itself rarely solves the problem. In small groups conflict is usually best faced through an integration process, the combination of everyone's ideas into group

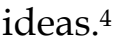

\section{Decision Making Process to Reduce Personal Conflicts}

Good personal conflicts are taken by "integration" to get consensus. The basis is that differences in thinking, feeling and behaving are most likely solved by incorporating the views of all parties into a decision or plan. Cooperative efforts can be achieved by finding, isolating and explaining the areas of agreement and contention, so systematically narrowing the field of difference and enlarge the field of acceptance.

According to Wayne, Peterson \& Burnet in the book tehnic for effective communication, two areas of difference need to be managed, namely differences in understanding and differences in feelings. To process in different understandings can be managed in three ways:

1. By discovering what people or other parties mean. Often a simple statement about what one means to avoid the advocacy of opposition.

2. By checking for evidence and reason wetness. Conflict and conflict often develop because two people mukin proposed the reasons of the same data and make different conclusions. You may want to find a source of evidence to determine the accuracy of the evidence.

3. By identifying a more fundamental value or purpose, which is sometimes called a superior goal. When disagreements are based on differences in preference or value, understanding may increase by identifying a more fundamental value that all parties accept

For differences based on feelings can be managed in five ways:

1. By increasing self-esteem of people who are against you. A fundamental source of emotional resistance is loss of face. No one wants to look stupid,

\footnotetext{
${ }^{4}$ Brown, David L. (1966). Managing Conflik at Organization Interface," Addison Wesley Publishing, p. 98
} 
illogical, or lost. Reduce feelings of dispassion by providing ego support or ways of enhancing self-esteem.

2. By creating a research atmosphere. Ask the group members to examine the problem by asking open-ended questions. Resistance often occurs because the alternative has not been reviewed.

3. By involving each group member in the discussion. Emotional constraints and negative feelings increase when we feel uninvited or not encouraged to make a contribution. Avoid silencing anyone, regardless of anything that may have been said.

4. Using the summary to show the group what has been achieved and what has not been achieved. Summaries can help to objectify comments and reduce generalizations and exaggerations. Group members are allowed to respond to a more objective summary that will ultimately divert emotional comments.

5. By providing opportunities to express feelings. Participants must have the opportunity to make highly emotional statements without argument or disclaimer. Many disagreements can be solved simply by allowing others freely to express their feelings.

Integrative decision making to reduce conflict stresses the importance of a combination of information, logic and feeling to achieve the best collective judgment of the group as a whole. Conflict is used in a cretive and conducive manner.

\section{Group Conflict}

When some groups feel frustrated because they can not achieve their goals, anatakelompok conflict occurs. Some groups look for sources of frustration within their own group, their own skills, methods, equipment and procedures. Other groups are looking for the source of their frustration from outside their group. When they think they have found the source of their frustration in another group, a process of conflict develops. There are seven circumstances that characterize this conflict:

1. Doubts and suspicions begin to surface, and climate among groups declines

2. Perceptions of external groups become distorted or polarized, with verbal comments separating good groups from bad groups

3. Related ties and feelings such as friendliness, attraction, kerkraban, and interests (importance) in each group increased 
4. Adherence to group norms and conformity also increases in each group

5. Groups prepare themselves for leadership and lead to authority.

6. Hostile behavior, reduced communicative relationships, and signs that cause differences in groups begin to appear

7. The existence of separation expected by all members of the group and any business cooperation stalled. ${ }^{5}$

\section{Decision Making Process to Reduce Group Conflict}

There are five ways to minimize group conflict:

1. Make sure that information to solve the problem is found and given to the groups involved. Other groups of biases regularly gather to study problem areas and make collective agreements

2. The similarity of each group member to the number of parts of the job

3. Make the groups closer to each other. Present opposing groups to explain the problem and allow them to different perceptions

4. Find the common enemy. An organization, private or government, can form conflicting groups and other groups unite to seek and fight their enemies. This can bring closer relationships between groups and reduce conflict

5. Identify or develop a common purpose device. This is the idea of finding a common goal for every group in the organization

\section{Method To Reduce The Conflict}

Stoner \& Freeman (Stoner, et.al, 1989: 400), found methods to reduce intergroup conflict

1. Each conflicting group is informed of the group to which they are dealing.

2. Enjoyable social contact between groups intensified, by eating together or watching together

3. Group leaders are asked to negotiate, and provide information about groups dealing with their groups.

${ }^{5}$ Stoner, James, A.F.R. Adward Freeman, (1988). Management", Englewood Cliffs: Printice hall Inc, p. 54 
Stoner also stated that there are three most commonly used methods of conflict resolution:

1. Domination or suppression; the decision to resolve the conflict is by suppressing the conflict or creating a defeat situation, in which the loser is forced to retreat to the higher authority.

2. Compromise; decisions are made to resolve conflicts by way of managers trying to resolve conflict, by believing the parties involved to tackle certain goals, in order to achieve other goals.

3. Integrative problem solving; where the parties involved trying to solve problems that arise between them. In this method there are 3 conflict solutions

4. Consensus, where the conflict is brought together to find the best solution, by not blaming or memenagngkan one group

5. Confrontation, conflict parties, express their views directly and openly to others. And studied the reasons for the conflict. With skilled leadership can often achieve a rational solution

\section{CONCLUSION}

In personal conflict there are five styles of conflict namely, competitors, collaborators, accomodators, compromiser and avoidance. How to meneylasaikan conflk this through the integration process. Conflict between groups there are seven stages that cause it, namely: doubt, perception, cohesiveness, compliance with the norm, self-preparation, hostile behavior and segregation of the group. Finally, the effect on groups to win or lose in competition and five ways to reduce this group conflict is to ensure information, equality in getting jobs, close relationships between groups, finding common enemies and identifying common goals between groups.

\section{BIBILIOGRAPHY}

Brown, David L. (1966). Managing Conflik at Organization Interface," Addison Wesley Publishing

J. Winardi (2003). Teori Organisasi dan Pengorganisasian, Jakarta: Raja Grafindo

Pace, R. Wayne \& Faules, Don. F. (2005). Komunikasi Organisasi, Strategi Meningkatkan Kinerja Perusahaan. Bandung: Remaja Rosdakarya 
Pace, R Wayne (1983). Organization communication, Faondation for Human Resource Development. New Jersey: Prentice Hall, Inc

Pondy, LR, (1976). Organization Conflik Management, in MD Dunnette (ed)", handbook of Industrial and Organization Psychology, Chicago: Rand McNally

Rivai, V. (2007). Kepemimpinan dan Prilaku Organisasi, Jakarta: Raja Grafindo

Stoner, James, A.F.R. Adward Freeman, (1988). Management", Englewood Cliffs: Printice hall Inc

Tampubolon, M. (2004). Prilaku Keorganisasian. Jakarta: Ghalia Indonesia. 